\title{
The Pathogenic Role of Cystathionine $\gamma$-Lyase/Hydrogen Sulfide in Streptozotocin-Induced Diabetes in Mice
}

\author{
Guangdong Yang, ${ }^{*}$ Guanghua Tang, ${ }^{\dagger}$ \\ Ling Zhang, ${ }^{\ddagger}$ Lingyun $\mathrm{Wu}^{\dagger}{ }^{\dagger}$ and Rui Wang ${ }^{\ddagger}$ \\ From the School of Kinesiology,* and the Department of Biology, ${ }^{*}$ \\ Lakehead University, Thunder Bay, Ontario; and the Department \\ of Pharmacology, University of Saskatchewan, Saskatoon, \\ Saskatchewan, Canada
}

Reduced $\beta$-cell mass and increased activities of ATPsensitive $\mathrm{K}^{+}$channels in pancreatic $\boldsymbol{\beta}$ cells are associated with the pathogenesis of diabetes. Cystathionine $\gamma$-lyase (CSE) is a major hydrogen sulfide $\left(\mathrm{H}_{2} \mathrm{~S}\right)$ producing enzyme in pancreatic $\beta$ cells. Herein, we examine the effects of genetic and pharmacologic ablation of CSE on $\beta$-cell functions and their correlation with streptozotocin (STZ)-induced diabetes. Compared with wild-type mice, CSE knockout (CSE KO) mice that received STZ injections exhibited a delayed onset of diabetic status. The application of DL-propargylglycine (PPG) to inhibit CSE activity protected wild-type mice from STZ-induced hyperglycemia and hypoinsulinemia. STZ significantly increased pancreatic $\mathrm{H}_{2} \mathrm{~S}$ production in wild-type mice but not in CSE KO mice. STZ induced more apoptotic $\beta$-cell death in wild-type mice than in CSE KO mice. STZ exposure decreased the viability of cultured INS-1E cells, which was partly reversed by PPG co-treatment. STZ also significantly stimulated $\mathrm{H}_{2} \mathrm{~S}$ production in cultured INS-1E cells. In addition, STZ stimulated ATP-sensitive $\mathrm{K}^{+}$currents in pancreatic $\boldsymbol{\beta}$ cells from wild-type mice but not in the presence of PPG or in $\beta$ cells from CSE KO mice. Sodium hydrosulfide injection instantly increased blood glucose, decreased plasma insulin, and deteriorated glucose tolerance in mice. Take together, these results provide evidence that the $\mathrm{CSE} / \mathrm{H}_{2} \mathrm{~S}$ system plays a critical role in regulating $\beta$-cell functions. (Am $J$ Pathol 2011, 179:869-879; DOI: 10.1016/j.ajpath.2011.04.028)

Hydrogen sulfide $\left(\mathrm{H}_{2} \mathrm{~S}\right)$ is a novel and important gasotransmitter. ${ }^{1-3} \mathrm{H}_{2} \mathrm{~S}$ has been reported to regulate cellular apoptosis and proliferation, ${ }^{4}$ protect the heart from ischemic damage, ${ }^{5}$ induce vasorelaxation and lower blood pressure, ${ }^{3}$ and alter insulin secretion and inflamma- tion. $^{6-8}$ Two pyridoxal-5'-phosphate-dependent enzymes, cystathionine $\beta$-synthase (CBS) (EC4.2.1.22) and cystathionine $\gamma$-lyase (CSE; also often named CTH) (EC 4.4.1.1), are responsible for most endogenous production of $\mathrm{H}_{2} \mathrm{~S}$ in mammalian tissues, which use L-cysteine as the main substrate. ${ }^{2,9}$ CSE seems to be the main $\mathrm{H}_{2} \mathrm{~S}$ forming enzyme in the pancreas. ${ }^{4,10}$ Recently, it was found that $\mathrm{H}_{2} \mathrm{~S}$ formation was significantly higher in the pancreas of Zuker diabetic fatty rats and streptozotocin (STZ)-induced diabetic rats compared with nondiabetic animals. ${ }^{10,11}$ As a substrate for $\mathrm{H}_{2} \mathrm{~S}$ production, cysteine level was also elevated in diabetic patients with diabetic nephropathy renal complications. ${ }^{12} \mathrm{H}_{2} \mathrm{~S}$ and cysteine inhibited insulin secretion from insulin-secreting $\beta$-cell lines (INS-1E, MIN6, and HIT-T15) or from isolated rat islets. ${ }^{6,8,13}$ Overexpression of CSE inhibited insulin release from INS-1E cells, but lowering endogenous $\mathrm{H}_{2} \mathrm{~S}$ production by DL-propargylglycine (PPG) or CSE-targeted small-interfering RNA had the opposite effect. ${ }^{6}$ Among demonstrated cellular and molecular mechanisms for pathophysiologic effects of $\mathrm{H}_{2} \mathrm{~S}$ on $\beta$ cells are the induction of cell apoptosis and the activation of ATP-sensitive $\mathrm{K}^{+}$ $\left(\mathrm{K}_{\mathrm{ATP}}\right)$ channels. ${ }^{4,6,13}$ We have shown that exogenously applied $\mathrm{H}_{2} \mathrm{~S}$ or endogenously produced $\mathrm{H}_{2} \mathrm{~S}$ derived from overexpressed CSE induced apoptosis of INS-1E cells, which suggests a novel role of the CSE/ $/ H_{2} S$ system in regulating pancreatic functions under physiologic conditions and in diabetes by stimulating $\beta$-cell apoptosis. ${ }^{5}$ In addition, we and others have shown that $\mathrm{H}_{2} \mathrm{~S}$ functions as an endogenous opener of $\mathrm{K}_{\text {ATP }}$ channels in $\beta$ cells independent of activation of cytosolic second messengers. ${ }^{6,13}$ Basal $\mathrm{K}_{\text {ATP }}$ channel currents were significantly reduced by lowering the endogenous $\mathrm{H}_{2} \mathrm{~S}$ level with CSE-small-interfering RNA transfection in INS-1E cells. ${ }^{6}$ Interaction of $\mathrm{H}_{2} \mathrm{~S}$ and $\mathrm{K}_{\text {ATP }}$ channels in insulin-secreting cells may constitute an important and novel mechanism for the fine control of insulin

Supported by an operating grant from the Canadian Diabetes Association and by a New Investigator award (G.Y.) and a postdoctoral fellowship (G.T.) from the Heart and Stroke Foundation of Canada.

Accepted for publication April 18, 2011.

Address reprint requests to Rui Wang, M.D., Ph.D., Office of Vice President (Research, Economic Development, and Innovation), Lakehead University, 955 Oliver Rd., Thunder Bay, ON, Canada P7B 5E1. E-mail: rwang@lakeheadu.ca. 
secretion from pancreatic $\beta$ cells. However, this interaction during the development of diabetes is still unclear.

Given that altered $\mathrm{H}_{2} \mathrm{~S}$ production is involved in the development of diabetes, inhibition of the $\mathrm{CSE} / \mathrm{H}_{2} \mathrm{~S}$ pathway may protect pancreatic $\beta$ cells from cytotoxic damage and suppress abnormal $\mathrm{K}_{\text {ATP }}$ channel activity. To test this hypothesis, we examined the relationship of pancreatic $\mathrm{CSE} / \mathrm{H}_{2} \mathrm{~S}$ activity and $\beta$-cell mass and functions using CSE knockout (CSE KO) mice ${ }^{14}$ or cultured $\beta$-cell lines. STZ was used to treat mice, and the development of diabetes was compared between CSE KO and wild-type mice. The effects of STZ on $\mathrm{H}_{2} \mathrm{~S}$ production and $\beta$-cell apoptosis and $\mathrm{K}_{\text {ATP }}$ channel activities were also investigated to probe the role of $\mathrm{H}_{2} \mathrm{~S}$ in STZ-induced diabetes.

\section{Research Design and Methods}

\section{Animal Preparation}

CSE KO mice were generated as previously described. ${ }^{14}$ The second and third generations of 10- to 16-week-old male CSE KO mice and age-matched male wild-type littermates on the C57BL/6J/129 background were used. PCR genotyping of CSE KO mice was performed using a three-primer assay in two reactions. ${ }^{14}$ All the animal experiments were conducted in compliance with the Guide for the Care and Use of Laboratory Animals published by the US NIH (publication No. 85-23, revised 1996) and approved by the Animal Health Care Committees of the University of Saskatchewan and Lakehead University. All the animals were maintained on standard rodent chow and had free access to food and water.

\section{Diabetes Model}

Mice (10 to 12 weeks old) were injected i.p. with STZ (40 $\mathrm{mg} / \mathrm{kg}$ ) between 10:00 AM and 11:00 AM for 5 consecutive days (days 1 to 5 ) to induce hyperglycemia. ${ }^{15,16}$ STZ was freshly dissolved in citrate buffer $(\mathrm{pH} 4.5)$; mice in the control group received an equal volume of citrate buffer alone. In some wild-type mice, PPG dissolved in PBS or PBS alone was injected i.p. at $40 \mathrm{mg} / \mathrm{kg} /$ day for 30 days (between 9:00 AM and 10:00 AM on days 1 to 30 ). Whole blood glucose concentration was measured in blood obtained from the tail vein of mice using OneTouch blood glucose strips (LifeScan, Milpitas, CA). Plasma insulin was measured using an enzyme-linked immunosorbent assay (ELISA) kit with mouse insulin as a standard (Mercodia AB, Uppsala, Sweden) according to the manufacturer's procedure. Blood samples were obtained from mice after overnight fasting unless otherwise specified. Blood plasma was prepared by spinning a tube of fresh blood containing EDTA $(1500 \times g$ for 15 minutes at $4^{\circ} \mathrm{C}$ ). Body weight and blood glucose level were measured every 3 to 4 days between 9:00 AM and 10:00 AM, and food and water intake were measured daily between 10:00 AM and 11:00 AM on days 25 to 30 .

\section{Cell Culture}

INS-1E cells derived from a rat insulinoma were cultured with RPMI 1640 medium supplemented with 10\% fetal bovine serum, $2.2 \mathrm{mg} / \mathrm{mL}$ of sodium bicarbonate, $1 \mathrm{mmol} / \mathrm{L}$ sodium pyruvate, $50 \mu \mathrm{mol} / \mathrm{L}$ 2-mercaptoethanol, $100 \mathrm{U} / \mathrm{mL}$ of penicillin, and $100 \mu \mathrm{g} / \mathrm{mL}$ of streptomycin, as previously described. ${ }^{6}$ The glucose concentration in the culture media was consistent at $3 \mathrm{mmol} / \mathrm{L}$. The experiments were performed when the cells reached $70 \%$ to $80 \%$ confluence between passages 56 and 70 . The cells were maintained overnight in serum-free media before treatment.

\section{Cellular Viability Assays}

The cultured INS-1E cells were serum starved overnight and then were subjected to 30 minutes of STZ exposure $(2 \mathrm{mmol} / \mathrm{L})$ the next day. After STZ exposure, the medium was replaced with fresh normal medium (10\% fetal bovine serum) without or with PPG $(200 \mu \mathrm{mol} / \mathrm{L})$ for another 24 hours. Quantification of cellular viability was made by using the MTT assay. ${ }^{4}$

\section{Measurement of Insulin Secretion}

Mouse islets were isolated by collagenase digestion as described elsewhere. ${ }^{10,17}$ Briefly, after the mice were anesthetized by i.p. injection of ketamine $\mathrm{HCl}$ and xylazine (80 mg/kg and $5 \mathrm{mg} / \mathrm{kg}$ body weight, respectively), pancreatic islets were digested with collagenase and were handpicked under a microscope. $\mathrm{Ca}^{2+}$-free medium consisting of $120 \mathrm{mmol} / \mathrm{L} \mathrm{NaCl}, 5 \mathrm{mmol} / \mathrm{L} \mathrm{KCl}, 2$ $\mathrm{mmol} / \mathrm{L} \mathrm{MgSO} 4,4 \mathrm{mmol} / \mathrm{L}$ glucose, $1 \mathrm{mmol} / \mathrm{L}$ EGTA, 25 $\mathrm{mmol} / \mathrm{L}$ HEPES- $\mathrm{NaOH}(\mathrm{pH} 7.4)$, and $1 \%(\mathrm{w} / \mathrm{v})$ bovine serum albumin was used for islet isolation. Isolated islets were washed and preincubated with glucose-free RPMI 1640 medium in 24 -well plates ( 10 islets per well). ${ }^{10}$ After 30 minutes of preincubation with $3 \mathrm{mmol} / \mathrm{L}$ glucose, the islets were incubated for 30 minutes at $37^{\circ} \mathrm{C}$ in the presence of $20 \mathrm{mmol} / \mathrm{L}$ glucose in a humidified atmosphere of $5 \% \mathrm{CO}_{2}$ and $95 \%$ air. At the end of each incubation period, the medium was collected and centrifuged for 10 minutes at $1500 \times g$ to remove islet debris. Insulin levels in the supernatants were determined using the mouse insulin ELISA kit (Mercodia AB).

\section{Electrophysiologic Recording of $K_{\text {ATP }}$ Channel Currents}

The patch clamp technique was used to record whole cell $\mathrm{K}_{\text {ATP }}$ currents of isolated single $\beta$ cells. ${ }^{6,10,18}$ Only cells in which $\mathrm{K}_{\text {ATP }}$ channel activity was significantly decreased by a high glucose level or by the $\mathrm{K}_{\text {ATP }}$ channel blocker glibenclamide were used in this study.

\section{Immunohistologic Analysis}

Mouse pancreases from each treatment group were dissected on day 30 after the first STZ injection and were immediately fixed in $4 \%$ buffered formalin. ${ }^{19}$ After the tis- 
sues were embedded in 22-oxacalcitriol compounds, $8-\mu \mathrm{m}$-thick sections were cut using a cryostat and were picked up on poly-L-lysine-coated slides. H\&E staining was performed as previously described. ${ }^{19}$ Primary antibody (guinea pig against swine insulin) was incubated in a humid chamber for 1 hour at 1:5000 dilution (DakoCytomation, Mississauga, ON, Canada). Second antibody fluorescein isothiocyanate-donkey anti-guinea pig (Jackson ImmunoResearch Laboratories Inc., West Grove, PA) was diluted at 1:500. Images were observed and analyzed using an inverted Olympus IX70 microscope (Olympus, Tokyo, Japan).

\section{Measurement of Apoptosis}

An in situ cell death detection kit (Hoffmann-La Roche Ltd., Mississauga, ON, Canada) was used to visualize the

A

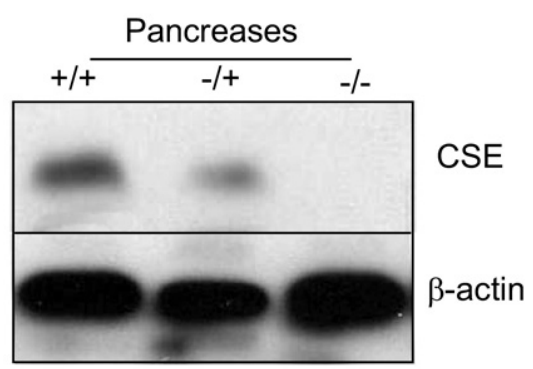

B

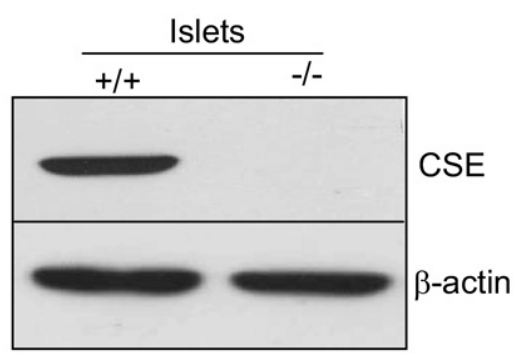

C

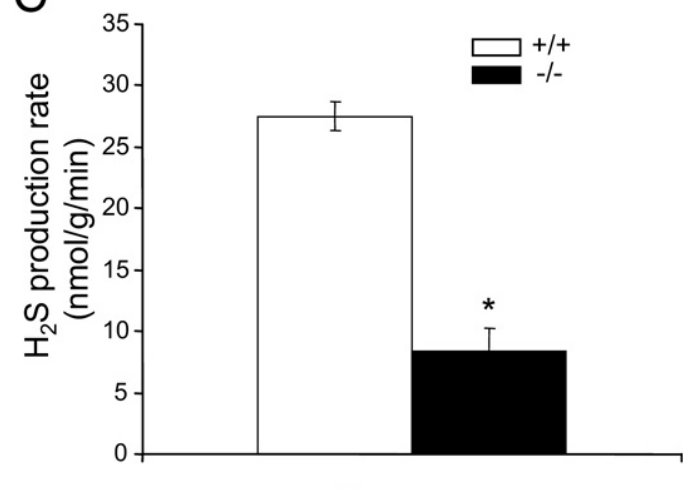

Pancreases

Figure 1. Lack of CSE expression and decrease in $\mathrm{H}_{2} \mathrm{~S}$ production in pancreases from CSE KO mice. Lack of CSE protein expression in pancreases (A) and islets (B) from CSE KO mice. $+/+$, wild-type mice; $-/+$, heterozygote mice; $-/-$, homozygote $(\mathrm{KO})$ mice. The results in $(\mathbf{A})$ and $(\mathbf{B})$ are representative of three independent experiments. C: Decreased $\mathrm{H}_{2} \mathrm{~S}$ production rate in pancreases from CSE KO mice. Values represent mean \pm SEM. $n=12$ wild-type mice and $n=15$ CSE KO mice. ${ }^{*} P<0.05$.
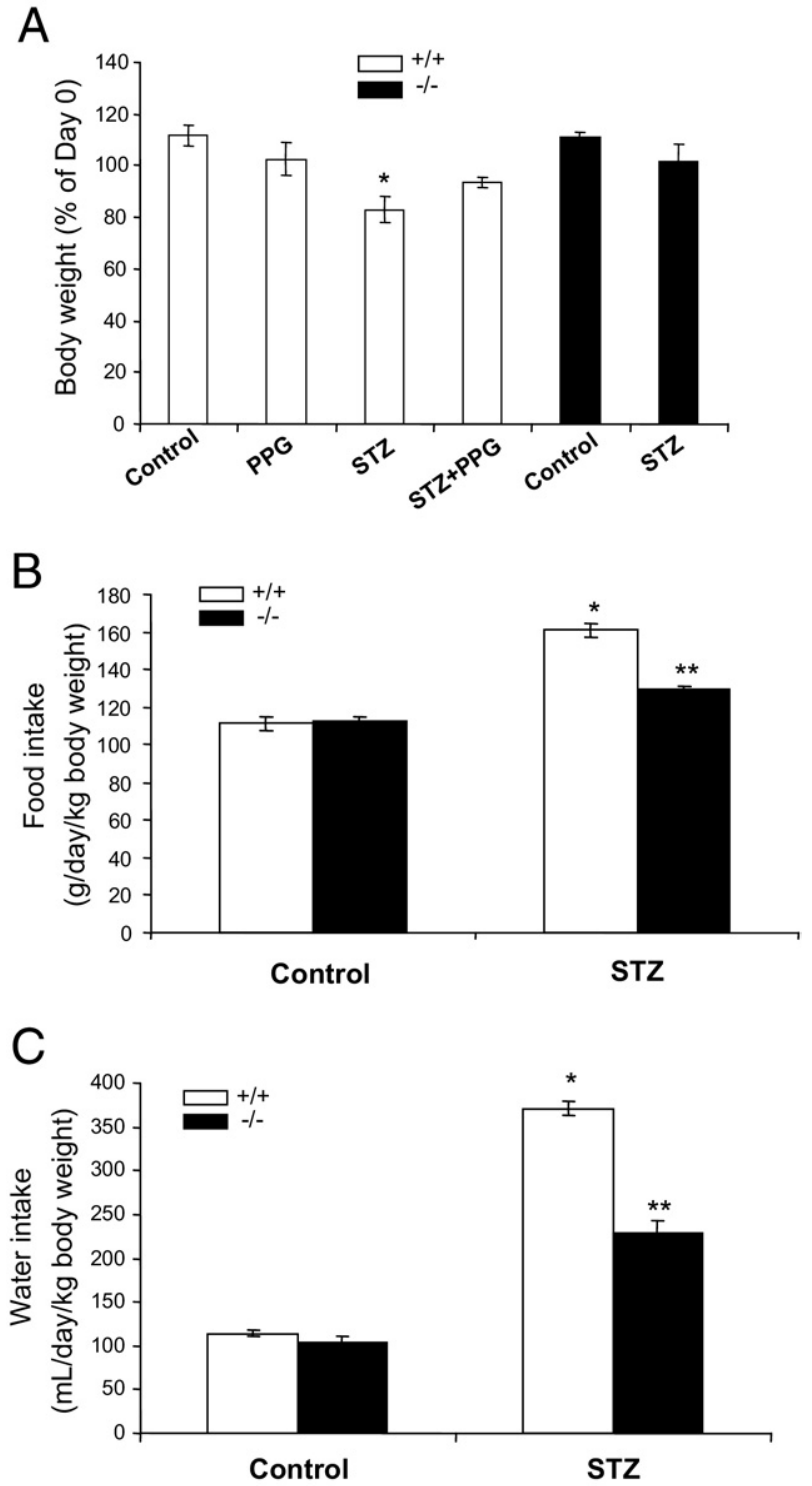

Figure 2. Reduced diabetic status in CSE KO mice induced by STZ. Increased body weights (A), decreased food intake (B), and decreased water intake $(\mathbf{C})$ in STZ-treated CSE KO mice. Values represent mean \pm SEM. Nine to 16 mice were used in each group. A: ${ }^{*} P<0.05$ versus all other groups. B and $\mathbf{C}:{ }^{*} P<0.05$ versus vehicle-treated mice; ${ }^{* * *} P<0.05$ versus STZ-treated wild-type mice. $+/+$, wild-type mice; $-/-$, CSE KO mice.

apoptotic pancreatic $\beta$ cells. ${ }^{20,21}$ Dual staining with terminal deoxynucleotidyl transferase-mediated dUTP nickend labeling (TUNEL) and insulin was performed. The nuclei were counterstained using DAPI (0.3 $\mu \mathrm{mol} / \mathrm{L}$; Molecular Probes Inc., Eugene, OR). Percentage of apoptosis was calculated by dividing the number of TUNELpositive $\beta$ cells by the total number of $\beta$-cell stained nuclei. At least 500 nuclei per pancreas were counted, and four mice per group were used.

\section{Western Blot Analysis and Measurement of $\mathrm{H}_{2} \mathrm{~S}$ Level}

Pancreatic tissues or isolated islets were obtained and lysed. ${ }^{10}$ The extracts were separated by centrifugation at 
$14,000 \times g$ for 15 minutes at $4^{\circ} \mathrm{C}$. SDS-PAGE and Western blot analysis were performed as described previously. ${ }^{4,10}$ The primary antibodies were diluted at 1:1000 for CSE (Novus Biologicals, Littleton, CO) and at 1:10,000 for $\beta$-actin (Sigma-Aldrich Canada Ltd., Oakville, ON, Canada). Horseradish peroxidase-conjugated secondary antibody was used at 1:5000 dilution. Immunoreactions were visualized by electrochemiluminescence and were exposed to X-ray film (Kodak scientific imaging film; Fisher Scientific Company, Ottawa, ON, Canada).

Endogenous $\mathrm{H}_{2} \mathrm{~S}$ productions from mouse pancreas tissues and INS-1E cells were measured as previously reported. $^{3,10}$

\section{Determination of mRNA Levels}

The mRNA expressions of CBS and glucose transporter 2 (Glut-2) in islets were measured by real-time PCR using an iCycler iQ3 apparatus (Bio-Rad Laboratories, Hercules, CA) associated with the iCycler optical system software (version 3.1) using SYBR green PCR master mix (Molecular Probes Inc.), as described previously. ${ }^{4}$ Briefly, all PCRs were performed in a volume of $20 \mu \mathrm{L}$ using 96-well optical-grade PCR plates and optical sealing tape. The cycling was conducted at $95^{\circ} \mathrm{C}$ for $90 \mathrm{sec}-$ onds followed by 38 cycles at $95^{\circ} \mathrm{C}$ for 10 seconds and at $60^{\circ} \mathrm{C}$ for 20 seconds. The primers of CBS (GenBank accession number NM_144855) were 5'-GGTGGTGGCGTCTGCGTGTTCA-3' (sense, position 1211-1232) and 5'-GCCCAGCGTGTCGGTCAGGT-3' (antisense, position 1460-1480). These primers produced a product of $270 \mathrm{bp}$. The primers of Glut-2 (GenBank accession number NM_031197) were 5'-GGATGCCAATTACCGACAGC-3' (sense, position 885-904) and 5'-AGGCGAATTTATCCAGCAGCACAA-3' (antisense, position 1157-1180). These primers produced a product of $296 \mathrm{bp}$. The primers of $\beta$-actin were purchased from Ambion (Austin, TX) and produced a product of $295 \mathrm{bp}$. A standard curve was constructed using a series of dilutions of total RNA (Ambion) transcribed to cDNA using the same protocol outlined previously herein to confirm the same amplifying efficiency in the PCR. A standard melting curve analysis was performed using the following thermal cycling profile: $95^{\circ} \mathrm{C}$ for $10 \mathrm{sec}$ onds, $55^{\circ} \mathrm{C}$ for 15 seconds, and ramping to $95^{\circ} \mathrm{C}$ in $1^{\circ}$ increments to confirm the absence of primer dimers. Relative mRNA quantification was calculated by using the fol-

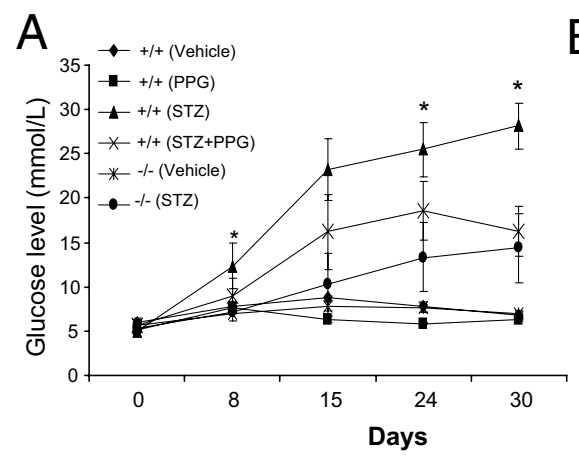

B
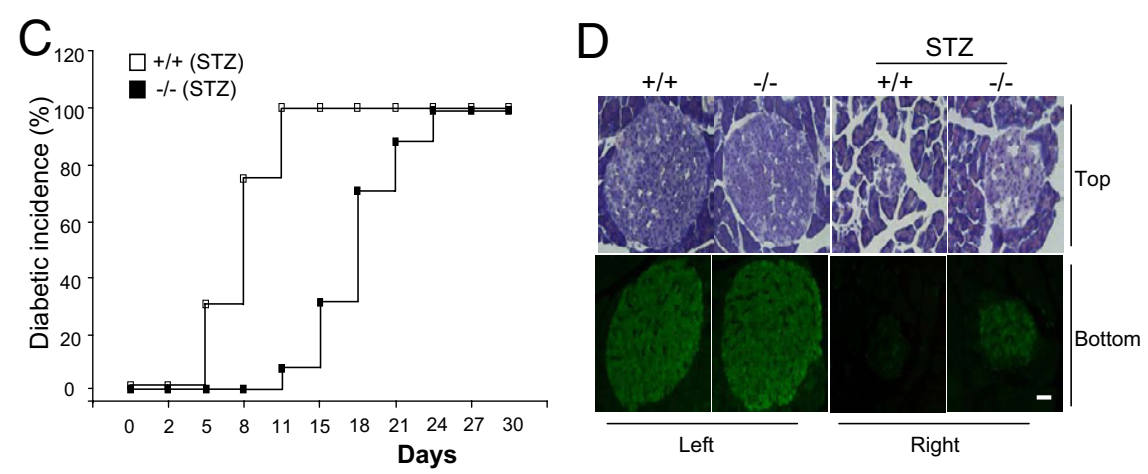

\section{E}

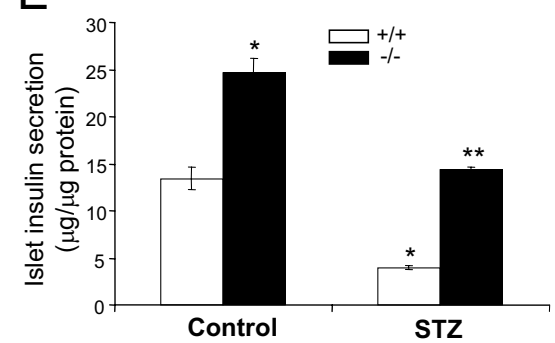

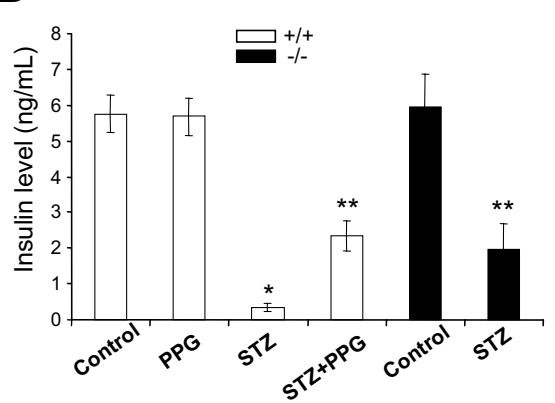

D

$\mathrm{F}$

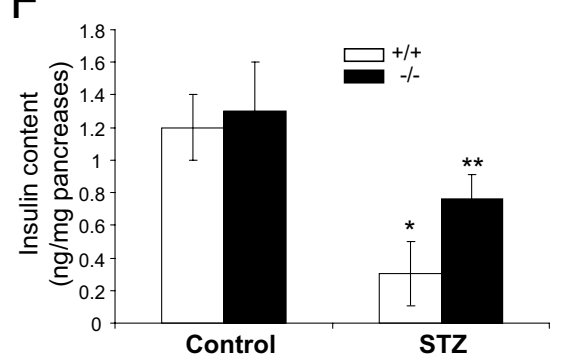

Figure 3. CSE deficiency protected mice from STZ-induced diabetes. Mice were injected with STZ ( $40 \mathrm{mg} / \mathrm{kg}$ body weight) for 5 days and/or with PPG (40 mg/kg body weight) for 30 days. A: Blood glucose concentration was measured in blood obtained from the tail vein using blood glucose strips twice a week. B: Plasma insulin level was measured using a mouse insulin ELISA kit at day 30 . Nine to 16 mice were used in each group. ${ }^{*} P<0.05$ versus all other groups; ${ }^{* * *} P<$ 0.05 versus STZ-treated wild-type mice. C: CSE $\mathrm{KO}$ mice showed a lower diabetic incidence induced by STZ. Fourteen CSE KO mice and 16 wild-type mice were used in this study. D: CSE deficiency protected against STZ-induced destruction of pancreatic islets. Pancreases were obtained from vehicle-treated mice (left) or STZtreated mice (right) on day 30. The morphologic features of the islets were processed with H\&E staining (top). Islets were also labeled with anti-insulin antibody and fluorescein isothiocyanate-labeled anti-guinea pig IgG and were examined by fluorescence microscope (bottom). Results are representative of two trials with at least three mice per group. Scale bar $=50 \mu \mathrm{m}$. E: Improved islet insulin release in CSE KO mice. After freshly isolated islets were incubated with $20 \mathrm{mmol} / \mathrm{L}$ glucose for 30 minutes, insulin levels in the media were measured using a mouse insulin ELISA kit. Three to six mice were used in each group. ${ }^{*} P<0.05$ versus vehicle-treated wild-type mice; ${ }^{* *} P<0.05$ versus vehicle-treated CSE KO mice. F: Decreased pancreatic insulin content in STZ-treated mice. Five mice were used in each group. ${ }^{*} P<0.05$ versus vehicletreated mice; ${ }^{* * *} P<0.05$ versus STZ-treated wildtype mice. Values represent mean \pm SEM. $+/+$, wild-type mice; -/-, CSE KO mice. 
lowing arithmetic formula: $2^{-\Delta \Delta} \mathrm{CT}$, where $\Delta \mathrm{CT}$ is the difference between the threshold cycle of a given target cDNA and an endogenous reference $\beta$-actin cDNA.

\section{Glucose and Insulin Tolerance Tests}

Glucose tolerance tests were performed in overnight-fasting mice on day 25 after STZ treatment; mice were injected i.p. with glucose (in saline) at $2 \mathrm{~g} / \mathrm{kg}$ body weight. Areas under the curve of the glucose tolerance test were calculated using trapezoidal integration. ${ }^{22}$ Insulin sensitivity tests were performed by i.p. injection of 2-hour-fasting mice (10 to12 weeks old) with insulin ( $1 \mathrm{U} / \mathrm{kg}$ body weight). Blood glucose concentrations and plasma insulin levels were assessed before and after injection. ${ }^{10}$

\section{Chemicals and Data Analysis}

Insulin was from Eli Lilly \& Co. (Indianapolis, IN). Chemicals were all obtained from Sigma-Aldrich unless otherwise mentioned. Data are presented as mean \pm SEM, representing at least three independent experiments. Statistical comparisons were made using the Excel 2003 spreadsheet program (Microsoft Corp., Redmond, WA), with the Student's $t$-test to evaluate the difference between two groups; the differences between multiple groups were analyzed using SPSS 10.0 software (SPSS Inc., Chicago, $\mathrm{IL}$ ), with analysis of variance and the post hoc Tukey's test. The significance level was set at $P<0.05$.

\section{Results}

\section{CSE Expression and $\mathrm{H}_{2} \mathrm{~S}$ Production in the Pancreas of CSE KO Mice}

CSE protein was not detected in pancreases and islets from CSE KO mice (Figure 1, A and B), and CSE protein expression in pancreases from heterozygotes was estimated to be half that in wild-type mice (Figure 1A). The $\mathrm{H}_{2} \mathrm{~S}$ production rate was significantly lowered in pancreases from CSE KO mice versus age-matched wild-type mice $(8.1 \pm 2.8 \mathrm{nmol} / \mathrm{g} /$ minute versus $27.2 \pm 2.7 \mathrm{nmol} /$ $\mathrm{g} /$ minute; $P<0.05$ ) (Figure $1 \mathrm{C}$ ).

\section{Resistance of CSE KO Mice to STZ-Induced Diabetes}

As shown in Figure 2A, the body weight of STZ-treated wild-type mice was significantly lower than that of vehicletreated wild-type mice or STZ-treated CSE KO mice $(P<$ 0.05), and the weight loss of STZ-treated wild-type mice was partly reversed by PPG treatment. STZ treatment had little effect on the body weight of CSE KO mice. Food and water intake were significantly higher in STZ-treated mice than in vehicle-treated mice (Figure 2, B and C). However, food and water intake were significantly lower in STZ-treated CSE KO mice than in STZ-treated wild-type mice $(P<0.05)$.

Blood glucose (Figure $3 \mathrm{~A}$ ) and plasma insulin (Figure 3B) levels were similar between wild-type and CSE KO mice. Injection of wild-type mice with STZ for 5 days resulted in progressive hyperglycemia (Figure $3 \mathrm{~A}$ ). At day 30 , STZ-treated wild-type mice had a significantly higher blood glucose level (28.2 $\pm 2.6 \mathrm{mmol} / \mathrm{L}) \mathrm{com}$ pared with vehicle-treated wild-type mice $(5.7 \pm 0.4$ $\mathrm{mmol} / \mathrm{L}$ ). Diabetes development in CSE KO mice was significantly delayed after STZ treatment, with the blood glucose level on day 30 being only $14.4 \pm 3.9 \mathrm{mmol} / \mathrm{L}$. Although the plasma insulin level in STZ-treated CSE KO mice was lower than that in vehicle-treated CSE KO mice $(1.98 \pm 0.69 \mathrm{ng} / \mathrm{mL}$ versus $5.95 \pm 0.91 \mathrm{ng} / \mathrm{mL} ; P<0.05)$, it was significantly higher than that of STZ-treated wildtype mice (0.33 $\pm 0.22 \mathrm{ng} / \mathrm{mL}$ ) (Figure 3B). By day 11 after STZ injection, none of the CSE KO mice were diabetic (fasting blood glucose level $>7.8 \mathrm{mmol} / \mathrm{L}$ ) compared with all 16 wild-type animals. All 14 CSE KO mice

\section{A}

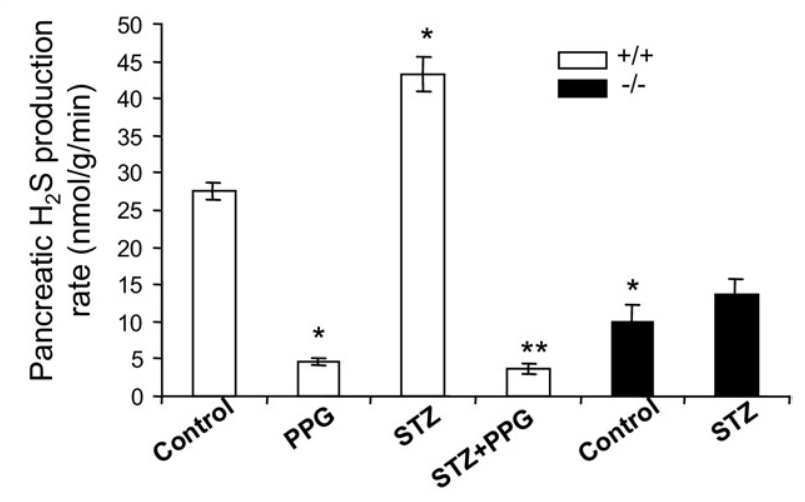

B
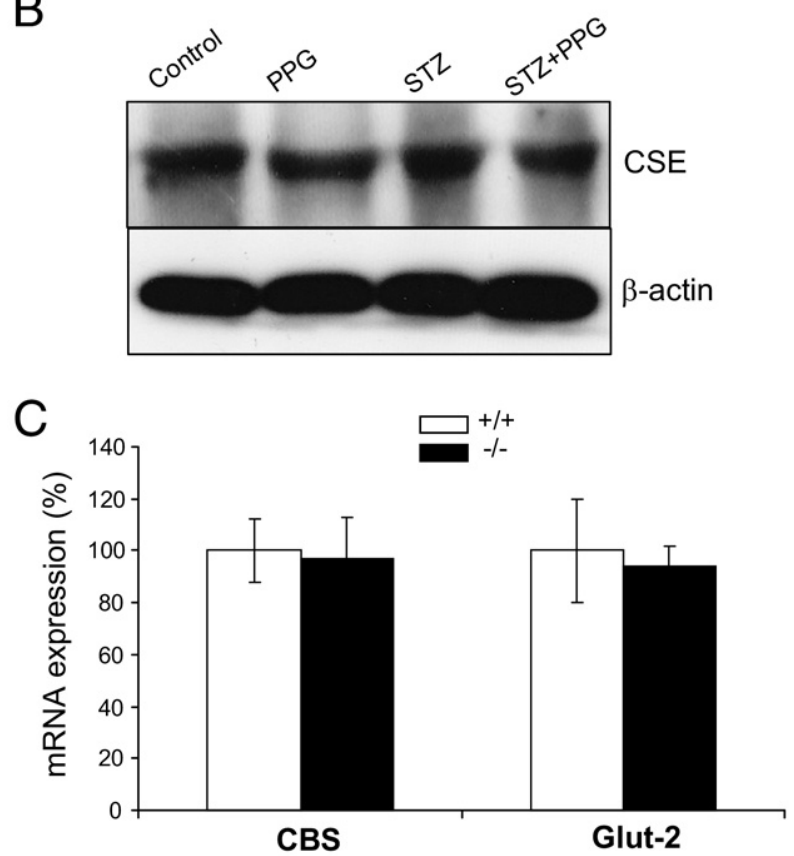

Figure 4. Increased $\mathrm{H}_{2} \mathrm{~S}$ production in STZ-treated wild-type mice. A: STZ treatment increased the $\mathrm{H}_{2} \mathrm{~S}$ production rate in pancreases of wild-type mice, which was significantly inhibited by PPG treatment. ${ }^{*} P<0.05$ versus vehicletreated wild-type mice; ${ }^{* * *} P<0.05$ versus STZ-treated wild-type mice. B: Neither STZ nor PPG changed CSE protein expression in the pancreas. C: No change in CBS and Glut-2 mRNA expressions between wild-type islets and CSE KO islets. Six to 16 mice were used in each group. Values represent mean \pm SEM. $+/+$, wild-type mice; -/-, CSE KO mice. 
developed diabetes by day 24 after STZ injection (Figure $3 C)$. By day 30 after STZ injection, all 14 CSE KO mice survived, but only 16 of 18 wild-type mice were alive. Treatment of wild-type mice with the CSE inhibitor PPG for 30 days partially protected the mice against STZinduced hyperglycemia (fasting blood glucose level, $16.3 \pm 2.8 \mathrm{mmol} / \mathrm{L}$ ) and hypoinsulinemia (plasma insulin level, $2.34 \pm 0.41 \mathrm{ng} / \mathrm{mL}$ ) compared with STZ-treated wild-type mice $(28.2 \pm 2.6 \mathrm{mmol} / \mathrm{L}$ and $0.33 \pm 0.22$ $\mathrm{ng} / \mathrm{mL}$ ). PPG treatment alone did not affect glucose and insulin levels in wild-type mice (Figure 3, A and B).

\section{CSE Deficiency Protects Against STZ-Induced Damage and Dysfunction of Pancreatic Islets}

To explore the role of CSE in STZ-induced diabetes, pancreatic tissues from STZ-treated mice at day 30 were subjected to $\mathrm{H} \& \mathrm{E}$ staining and immunohistochemical (IHC) analysis. The morphologic features of islets in vehicletreated wild-type mice and CSE KO mice were similar, both showing a round shape and clearly identifiable islets with strong insulin-positive staining (Figure 3D, left). In wild-type mice treated with STZ, the number of islets was greatly reduced, and the remaining islets were smaller and distorted in appearance, with fewer cells stained for insulin (Figure 3D). In striking contrast, CSE KO islets were partly protected from this damage, displaying more insulin staining, with the overall morphologic appearance essentially comparable with that of wild-type mice treated with STZ (Figure 3D, right). Furthermore, $20 \mathrm{mmol} / \mathrm{L}$ glucose stimulated greater insulin release $(24.8 \pm 1.5 \mu \mathrm{g} / \mu \mathrm{g}$ protein) from CSE KO islets compared with that from wild-type islets (13.4 $\pm 2.1 \mu \mathrm{g} / \mu \mathrm{g}$ protein; $P<0.05$ ) (Figure 3E). STZ treatment significantly repressed glucose-stimulated insulin release from CSE KO islets (14.2 $\pm 0.5 \mu \mathrm{g} / \mu \mathrm{g}$ protein) and wild-type islets $(4.0 \pm 0.3 \mu \mathrm{g} / \mu \mathrm{g}$ protein), and this effect was more significant with wild-type islets $(P<0.05)$. The insulin contents of whole pancreases from vehicle- and STZ-treated mice were also assayed. There was no appreciable difference in insulin content between vehicle-treated wild-type and CSE KO mice. However, STZ treatment significantly decreased pancreatic insulin content in wild-type and CSE KO mice, with a more significant effect on wildtype mice $(P<0.05)$ (Figure 3F).

\section{Stimulated $\mathrm{H}_{2} \mathrm{~S}$ Production by STZ in Mice}

The $\mathrm{H}_{2} \mathrm{~S}$ production rate of the pancreas of STZ-treated wild-type mice $(43.3 \pm 2.4 \mathrm{nmol} / \mathrm{g} / \mathrm{min})$ was significantly higher than that of vehicle-treated wild-type mice (27.5 \pm $1.2 \mathrm{nmol} / \mathrm{g} / \mathrm{min}$ ) (Figure 4A). STZ did not affect pancreatic $\mathrm{H}_{2} \mathrm{~S}$ production in CSE KO mice $(13.6 \pm 2.0 \mathrm{nmol} / \mathrm{g} / \mathrm{min})$ compared with vehicle-treated CSE KO mice $(10.1 \pm 2.3$ $\mathrm{nmol} / \mathrm{g} / \mathrm{min})$. PPG treatment significantly decreased $\mathrm{H}_{2} \mathrm{~S}$ production in pancreases of vehicle- and STZ-treated wild-type mice $(4.5 \pm 0.6 \mathrm{nmol} / \mathrm{g} / \mathrm{min}$ and $4.0 \pm 0.8$ $\mathrm{nmol} / \mathrm{g} / \mathrm{min}$ ). However, neither STZ nor PPG affected CSE protein expression in pancreas from wild-type mice (Figure $4 \mathrm{~B})$. The expression of CBS and Glut-2 mRNA was not different between wild-type and CSE KO islets (Figure 4C).

\section{Involvement of the CSE/ $\mathrm{H}_{2} \mathrm{~S}$ System in} STZ-Induced $\beta$-Cell Apoptosis

The apoptotic status of $\beta$ cells in islets of STZ-treated wild-type and CSE KO mice was tested. More apoptotic $\beta$ cells were found in islets of STZ-treated wild-type mice than in islets of STZ-treated CSE KO mice $(51.6 \% \pm$

A

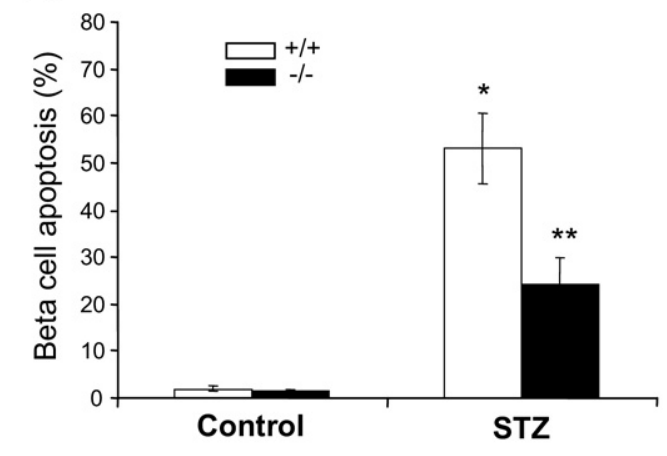

B

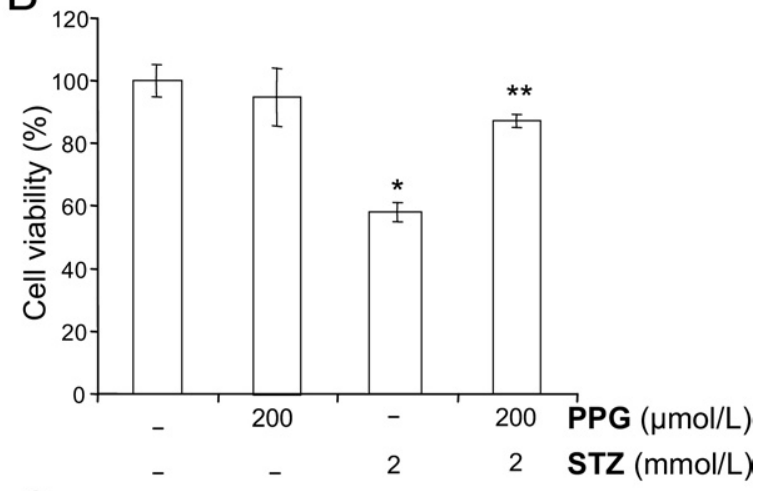

C

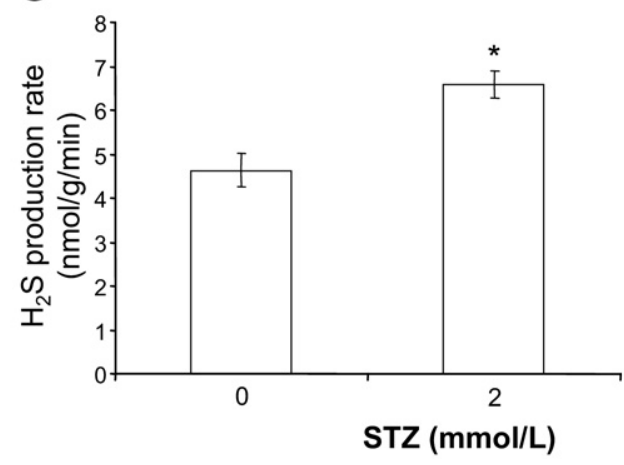

Figure 5. CSE deficiency repressed STZ-induced $\beta$-cell apoptosis. A: $\beta$-cell apoptosis was significantly decreased in STZ-treated CSE KO mice. ${ }^{*} P<0.05$ versus vehicle-treated mice; ${ }^{* * *} P<0.05$ versus STZ-treated wild-type mice. $\beta$-cell apoptosis was processed for TUNEL staining. TUNEL-positive $\beta$ cells were quantified and are expressed as percentage of total $\beta$ cells. Four mice were used in each group. B: STZ decreased INS-1E cell viability, which was significantly reversed by PPG treatment. INS-1E cells were first incubated with $2 \mathrm{mmol} / \mathrm{L}$ STZ for 30 minutes, and the cells were allowed to recover for 24 hours in the presence or absence of $200 \mu \mathrm{mol} / \mathrm{L}$ PPG. ${ }^{*} P<0.05$ versus all other groups; ${ }^{* * *} P<0.05$ versus STZ-treated cells. C: STZ increased $\mathrm{H}_{2} \mathrm{~S}$ production in INS-1E cells. The cells were first incubated with $2 \mathrm{mmol} / \mathrm{L}$ STZ for 30 minutes, and then fresh medium was added for another 24 hours. ${ }^{*} P<0.05$. The experiments in $\mathbf{B}$ and $\mathbf{C}$ were repeated at least four times. Values represent mean \pm SEM. $+/+$, wild-type mice; $-/-$, CSE KO mice. 
$10.7 \%$ versus $24.7 \% \pm 8.2 \% ; P<0.05$ ) (Figure $5 \mathrm{~A}$ ). Fewer apoptotic $\beta$ cells were found in vehicle-treated mice. A 30-minute STZ exposure followed by a 24-hour recovery significantly decreased the viability of cultured INS-1E cells $(P<0.05)$, which was reversed by cotreating the cells with PPG (Figure 5B). PPG alone did not affect cell viability. In addition, STZ incubation significantly stimulated $\mathrm{H}_{2} \mathrm{~S}$ production in INS-1E cells by 43.4\% $(P<0.05$; Figure 5C).

\section{Mediation of STZ-Stimulated $K_{\text {ATP }}$ Channels in $\beta$ Cells by the CSE $/ \mathrm{H}_{2} \mathrm{~S}$ System}

In single $\beta$ cells from wild-type mice, glucose-sensitive $\mathrm{K}_{\text {ATP }}$ currents were suppressed by the $\mathrm{K}_{\text {ATP }}$ channel blocker glibenclamide at $10 \mu \mathrm{mol} / \mathrm{L}$ (from -2851.6 \pm $210.7 \mathrm{pA}$ to $-1430.4 \pm 153.2 \mathrm{pA} ; P<0.05)$ and enhanced by the $\mathrm{K}_{\text {ATP }}$ channel opener pinacidil at 100 $\mu \mathrm{mol} / \mathrm{L}$ (from $-2438.2 \pm 235.6 \mathrm{pA}$ to $-4106.3 \pm 398.4$
pA; $P<0.05)$. STZ stimulated $\mathrm{K}_{\text {ATP }}$ currents by $38.5 \% \pm$ 8.0\% $(P<0.05$; Figure $6, A$ and $B)$. The stimulatory effect of STZ reached the maximum level in 5 minutes (Figure 6C). STZ-stimulated $\mathrm{K}_{\text {ATP }}$ currents were reversible by washout (Figure $6, A-C$ ). In the presence of PPG in the pipette solution, STZ increased $\mathrm{K}_{\text {ATP }}$ currents by only $8.3 \% \pm 1.7 \%$ compared with that in the absence of PPG dialysis (Figure $6, A-C)$. Furthermore, STZ did not to stimulate $K_{\text {ATP }}$ currents in $\beta$ cells isolated from CSE KO mice compared with those from wild-type mice $(P<0.05)$ (Figure $6, D-F)$. These results suggest that the $\mathrm{CSE} / \mathrm{H}_{2} \mathrm{~S}$ system mediates the effect of STZ on $\mathrm{K}_{\text {ATP }}$ channels in pancreatic $\beta$ cells.

\section{Effects of the CSE/ $\mathrm{H}_{2} \mathrm{~S}$ System on Glucose Tolerance in Mice}

The i.p. glucose tolerance test demonstrated that CSE $\mathrm{KO}$ mice had significantly lower blood glucose concentrations $(12.1 \pm 0.6 \mathrm{mmol} / \mathrm{L})$ than did wild-type mice
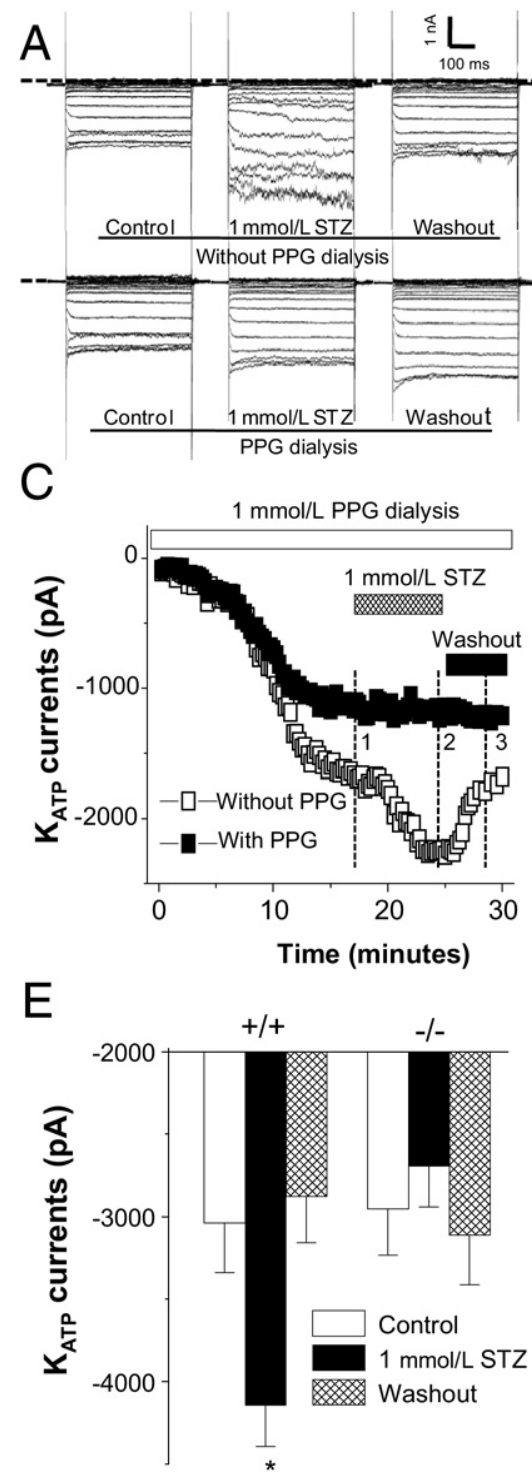

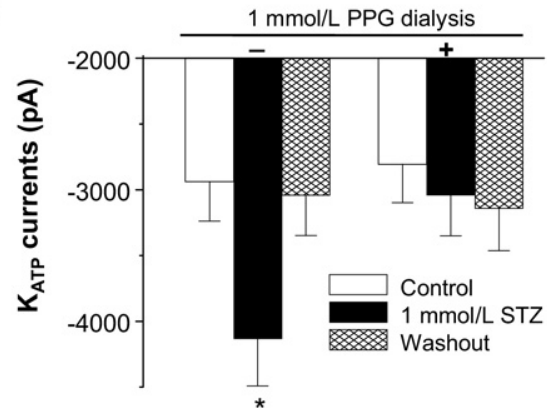

D

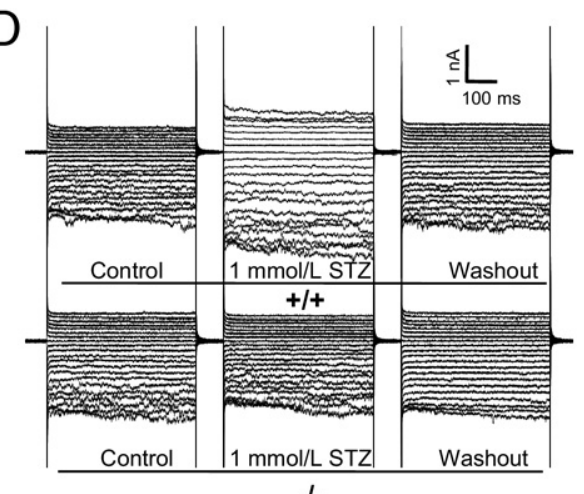

F

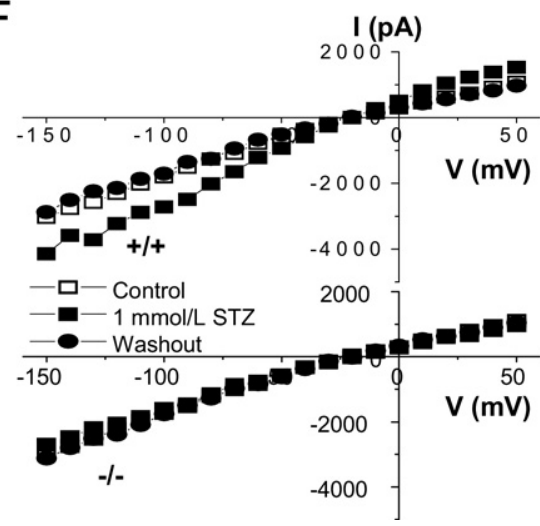

Figure 6. STZ-stimulated $\mathrm{K}_{\mathrm{ATP}}$ channels in $\beta$ cells were mediated by the $\mathrm{CSE} / \mathrm{H}_{2} \mathrm{~S}$ system. A: The original current traces showed that STZ stimulated $\mathrm{K}_{\mathrm{ATP}}$ currents in pancreatic islet $\beta$ cells from wild-type mice, which was abolished by the dialysis of $1 \mathrm{mmol} / \mathrm{L}$ PPG. The step pulse was from -150 to $60 \mathrm{mV}$, with the increment of $10 \mathrm{mV}$, with the holding potential of $-20 \mathrm{mV}$ The dashed horizontal line indicates zero current. The graph in $\mathbf{B}$ was summarized from the original current traces in $\mathbf{A} .{ }^{*} P<0.05$ versus all other groups. Thirteen cells were used in these experiments. C: The time course of STZ effects on $\mathrm{K}_{\mathrm{ATP}}$ currents in islet $\beta$ cells from wild-type mice in the presence or absence of PPG. The dashed vertical lines (1,2, and 3 ) indicate time points for the $\mathrm{K}_{\mathrm{ATP}}$ current recording in $\mathbf{A}$. D: The original current traces show that CSE KO abolished STZ-stimulated $\mathrm{K}_{\mathrm{ATP}}$ currents in $\beta$ cells. The graph in $\mathbf{E}$ was summarized from the original current traces in $\mathbf{D}$. ${ }^{*} P<0.05$ versus all other groups. Seven cells were used in these experiments. F: The summarized corresponding I-V relationship curves from $\mathbf{D}$. Values represent mean \pm SEM. $+/+$, wild-type mice; $-/-$, CSE $\mathrm{KO}$ mice. 
A

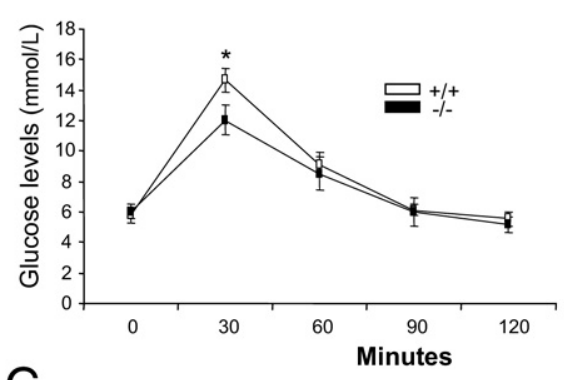

C

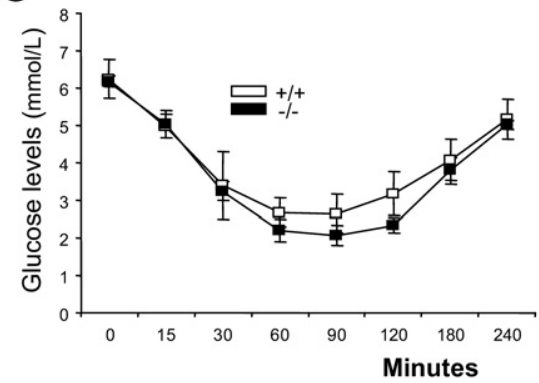

E

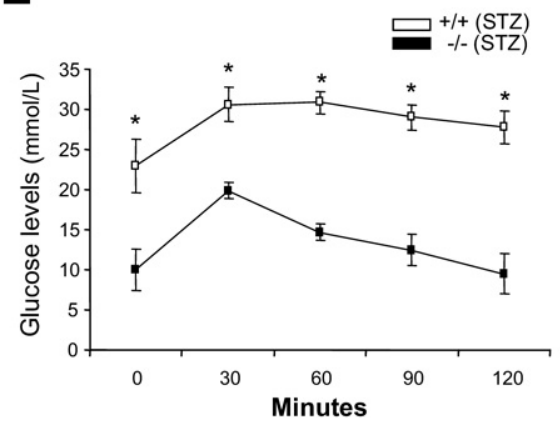

$\mathrm{B}$

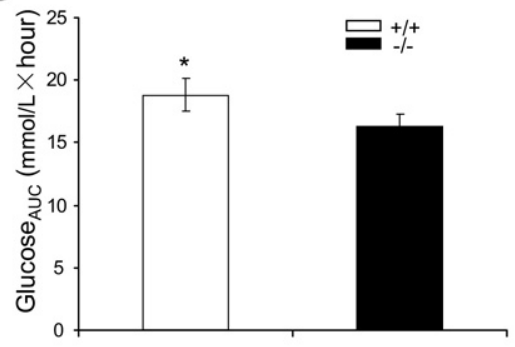

D

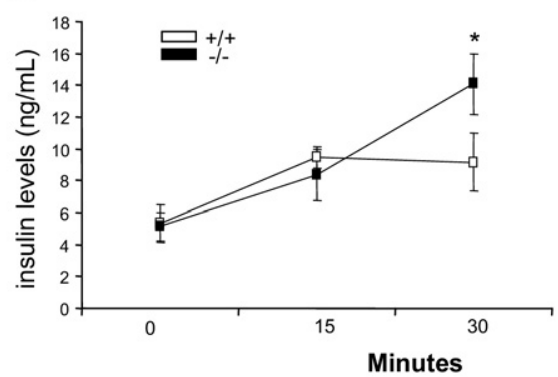

$\mathrm{F}$

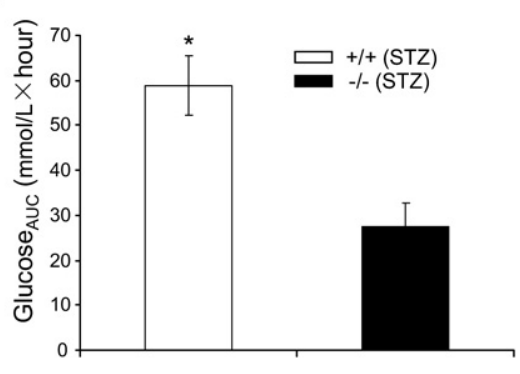

Figure 7. Improved glucose tolerance in CSE KO mice. CSE KO mice displayed improved glucose tolerance (A) without alterations in insulin sensitivity (C). The blood glucose concentration of 12-week-old mice was monitored for 2 hours after i.p. injection of $2 \mathrm{~g} / \mathrm{kg}$ body weight glucose (overnight fasting) or 4 hours after i.p. injection of $1 \mathrm{U} / \mathrm{kg}$ body weight insulin (2-hour fasting). Six to eight mice were used in each group. ${ }^{*} P<$ 0.05 versus CSE KO mice at the same time point D: Glucose stimulated more insulin release in CSE KO mice. Plasma insulin level was measured at different times after the mice were i.p. injected with glucose, $2 \mathrm{~g} / \mathrm{kg}$ body weight. Five mice were used in each group. ${ }^{*} P<0.05$ versus CSE KO mice at the same time point. E: STZtreated CSE KO mice displayed improved glucose tolerance. The blood glucose concentrations of STZ-treated mice were monitored for 2 hours after i.p. injection of $2 \mathrm{~g} / \mathrm{kg}$ body weight (overnight fasting). Five to six mice were used in each group. ${ }^{*} P<0.05$ versus CSE KO mice at the same time point. $\mathbf{B}$ and $\mathbf{F}$ : The areas under the curve of the glucose tolerance test (Glucose in $\mathbf{A}$ and $\mathbf{E}$ were calculated using the trapezoidal rule. ${ }^{*} P<0.05$. Values represent mean \pm SEM $+/+$, wild-type mice; $-/-$, CSE KO mice.
(14.7 $\pm 0.4 \mathrm{mmol} / \mathrm{L} ; P<0.05) 30$ minutes after glucose load (Figure 7A), and both groups of mice returned their blood glucose levels back to normal within 2 hours. Compared with wild-type mice, the value of the area under the curve of the glucose tolerance test was markedly lower in CSE KO mice (Figure 7B). Insulin sensitivity tests showed that there were no differences between wild-type and CSE KO mice (Figure 7C). In addition, glucose load stimulated insulin release in wild-type and CSE KO mice, and it became more significant in CSE KO mice 30 minutes after glucose load (Figure 7D). Glucose tolerance tests were also performed in STZ-treated wild-type and CSE $\mathrm{KO}$ mice. CSE KO mice showed lower blood glucose levels than did wild-type mice at all the time points $(P<$ 0.05) (Figure 7E). Furthermore, the increase in circulating glucose levels was transient and gradually returned to basal levels within 2 hours in STZ-treated CSE KO, whereas blood glucose concentration remained high in STZ-treated wild-type mice. The area under the curve of the glucose tolerance test in STZ-treated wild-type mice was 2.1 times of that in STZ-treated CSE KO mice (Figure 7F). These results indicate that STZ-treated CSE KO mice had a normal response to a glucose load compared with STZ-treated wild-type mice.
In another group of experiments, 10- to 12-week-old wild-type mice (overnight fasting) were injected with sodium hydrosulfide (NaHS) (39 $\mu \mathrm{mol} / \mathrm{kg}$ body weight) 10 minutes before the injection of glucose. NaHS pretreatment significantly deteriorated the glucose tolerance of wild-type mice, whereas NaHS alone had no effect on blood glucose levels of these mice (Figure 8A). We found that blood glucose concentrations were significantly increased in nonfasting wild-type mice compared with overnight-fasting wild-type mice 40 minutes after NaHS injection (Figure 8B). NaHS administration also significantly reduced insulin release in nonfasting wild-type mice but not in overnight-fasting wild-type mice (Figure 8C).

\section{Discussion}

Type 1 diabetes mellitus (T1DM) is a chronic metabolic disorder characterized by a loss of pancreatic islet $\beta$-cell mass, decreased plasma insulin levels, and hyperglycemia. ${ }^{23-25}$ Although the pathogenic mechanisms for this disease have not been fully characterized, genetic, environmental, and autoimmune factors have been postulated. ${ }^{21,25}$ Recently, a pathogenic role of the $\mathrm{CSE} / \mathrm{H}_{2} \mathrm{~S}$ 
A

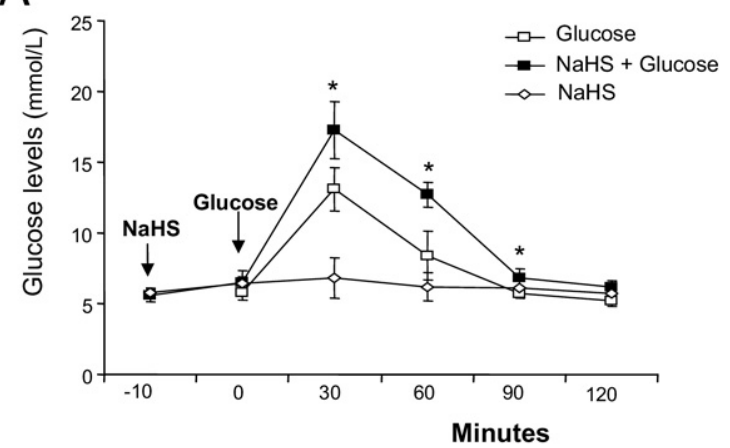

B

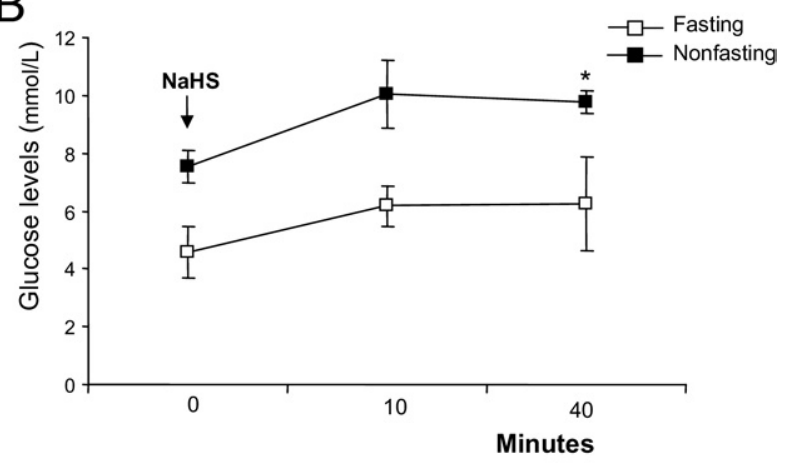

C

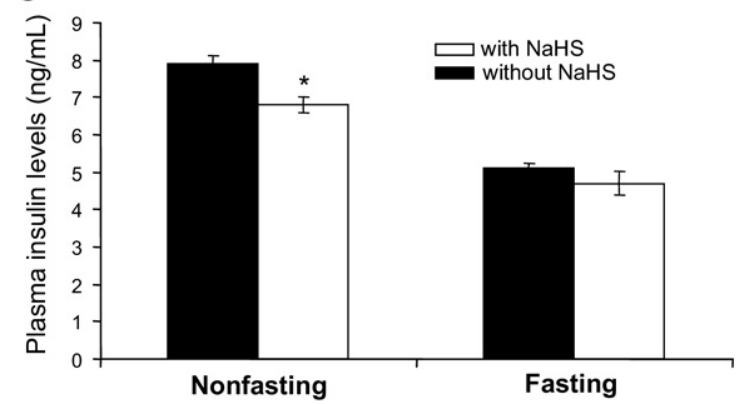

Figure 8. NaHS deteriorated glucose tolerance in mice. A: NaHS injection deteriorated glucose tolerance in wild-type mice. Wild-type mice (10 to 12 weeks old, overnight fasting) were i.p. injected with NaHS ( $39 \mu \mathrm{mol} / \mathrm{kg}$ body weight) and/or glucose ( $2 \mathrm{~g} / \mathrm{kg}$ body weight), and blood glucose was measured at different time point. Five to eight mice were used in each group. ${ }^{*} P<0.05$ versus all other groups at the same time point. B: NaHS increased blood glucose levels in nonfasting mice. Nonfasting or overnight-fasting wild-type mice (10 to 12 weeks old) were injected with NaHS $(39 \mu \mathrm{mol} / \mathrm{kg}$ body weight), and blood glucose was measured at different time points. Five mice were used in each group. ${ }^{*} P<0.05$ versus nonfasting mice without NaHS injection. C: NaHS decreased insulin release in nonfasting mice. Plasma insulin level was measured 40 minutes after the mice were injected with NaHS ( $39 \mu \mathrm{mol} / \mathrm{kg}$ body weight). Five mice were used in each group. ${ }^{*} P<0.05$ versus nonfasting mice without NaHS injection. Values represent mean \pm SEM.

system in T1DM has been suggested. ${ }^{26-31}$ Does the pancreatic production of endogenous $\mathrm{H}_{2} \mathrm{~S}$ change the development of T1DM? Could $\mathrm{H}_{2} \mathrm{~S}$ be a therapeutic target for T1DM management? To address these questions, we conducted the present study.

STZ is a glucosamine-nitrosourea compound that shows selective cytotoxicity to pancreatic $\beta$ cells and is widely used to generate the T1DM model. ${ }^{32}$ STZ is transported into the cell by Glut-2 but is not recognized by the other glucose transporters. Pancreatic $\beta$ cells have rela- tively high levels of Glut-2. Once inside $\beta$ cells, STZ decomposes into alkylating agents, which directly cause DNA damage, which is one of the proposed molecular mechanisms of STZ-induced cell damage. ${ }^{32,33}$ In the present study, we demonstrated that injecting wild-type mice with low-dose STZ (40 mg/kg body weight) for 5 consecutive days resulted in severe hyperglycemia, hypoinsulinemia, body weight loss, major glucose intolerance, and disappearance of pancreatic $\beta$ cells, as has previously been reported. ${ }^{16,17}$ The prodiabetic effect of STZ seems to be mediated by increased CSE activity because an irreversible CSE inhibitor, PPG, partially suppressed STZ-induced hyperglycemia and hypoinsulinemia. The solid evidence for this notion was derived from our novel observation that STZ-generated diabetes development was delayed in CSE KO mice. There was no difference in Glut-2 mRNA expression between wild-type and CSE KO islets, suggesting that the uptake of STZ into $\beta$ cells should be equal between these two groups (Figure $4 \mathrm{C}$ ). Two putative mechanisms may explain this delayed occurrence of diabetes in CSE KO mice, both related to the stimulation of CSE and increased $\mathrm{H}_{2} \mathrm{~S}$ production by STZ. $\mathrm{H}_{2} \mathrm{~S}$ increased pancreatic $\beta$-cell apoptosis, which would reduce $\beta$-cell mass and insulin production. $\mathrm{H}_{2} \mathrm{~S}$ activated $\mathrm{K}_{\text {ATP }}$ channels, which would reduce insulin release. $\mathrm{K}_{\text {ATP }}$ channel activation also influences cell viability, and suppression of $\mathrm{K}_{\text {ATP }}$ channel activity protects murine pancreatic $\beta$ cells against oxidative stress. ${ }^{34,35}$

In the present study, we found that STZ treatment significantly increased pancreatic $\mathrm{H}_{2} \mathrm{~S}$ production in wildtype mice but not in CSE KO mice (Figure 4A), suggesting that the overproduced $\mathrm{H}_{2} \mathrm{~S}$ is mainly derived from CSE. In vitro study also showed that STZ stimulated $\mathrm{H}_{2} \mathrm{~S}$ production in INS-1E cells (Figure 5C). We did not find any difference in CSE protein expression from pancreatic islets between vehicle-treated and STZ-treated wild-type mice (Figure 4B), suggesting that STZ may directly stimulate CSE activity at posttranslational levels to increase $\mathrm{H}_{2} \mathrm{~S}$ production. Alternatively, STZ may stimulate CSE protein expression, which is counteracted by the effect of high glucose level. A previous study showed that high glucose levels inhibited $\mathrm{H}_{2} \mathrm{~S}$ production in INS-1E cells. ${ }^{6}$

STZ injection caused extensive $\beta$-cell apoptosis in the islets of wild-type mice and loss of functional $\beta$ cells (Figure 5A). In contrast, the extent of islet $\beta$-cell death and dysfunction was markedly less in STZ-treated CSE $\mathrm{KO}$ mice. The significant decrease in $\mathrm{H}_{2} \mathrm{~S}$ production in pancreases due to CSE deficiency may protect CSE KO mice from STZ-induced $\beta$-cell death. Recently, we showed that exogenously applied $\mathrm{H}_{2} \mathrm{~S}$ or endogenously produced $\mathrm{H}_{2} \mathrm{~S}$ derived from overexpressed CSE induced apoptosis of INS-1E cells via endoplasmic reticulum stress. ${ }^{4}$ Herein, we demonstrated that a 30-minute STZ exposure followed by a 24-hour recovery significantly decreased INS-1E cell viability, which was partly reversed by co-treating the cells with PPG (Figure 5B). All these findings indicate that the $\mathrm{CSE} / \mathrm{H}_{2} \mathrm{~S}$ system mediates STZ-induced apoptosis of pancreatic $\beta$ cells.

It is well-known that $\mathrm{H}_{2} \mathrm{~S}$ functions as an endogenous opener of $\mathrm{K}_{\text {ATP }}$ channels in $\beta$ cells. ${ }^{6,13}$ Glucose metabo- 
lism stimulates insulin secretion from pancreatic $\beta$ cells by closing $\mathrm{K}_{\text {ATP }}$ channels, thereby inducing $\beta$-cell depolarization, calcium influx, and insulin exocytosis. Conversely, opening of $\mathrm{K}_{\text {ATP }}$ channels prevents insulin secretion by causing $\beta$-cell hyperpolarization. ${ }^{36,37}$ The present study found that STZ stimulated $\mathrm{K}_{\text {ATP }}$ channel currents in single $\beta$ cells from wild-type mice but not those from CSE $\mathrm{KO}$ mice, and the stimulatory effect of STZ on $\mathrm{K}_{\mathrm{ATP}}$ channels was abolished by PPG dialysis. These observations indicate that STZ stimulates $\mathrm{K}_{\text {ATP }}$ channels by increasing endogenous $\mathrm{H}_{2} \mathrm{~S}$ production, and increased $\mathrm{K}_{\text {ATP }}$ channel activity causes a diabetic state due to the reduced secretion of insulin. This may also explain why $\mathrm{K}_{\text {ATP }}$ channels do not respond to STZ stimulation in CSE KO mice.

The endogenous production and physiologic function of $\mathrm{H}_{2} \mathrm{~S}$ in the pancreas have been confirmed, and the expression of CBS and CSE in rat and mouse pancreatic tissues or the cloned pancreatic $\beta$-cell line has been reported. ${ }^{6,10,11}$ We have shown that CSE is the major $\mathrm{H}_{2} \mathrm{~S}$-generating enzyme in pancreatic islets because the expression level of CSE mRNA was significantly higher than that of CBS in pancreatic islets; and PPG abolished the most $\mathrm{H}_{2} \mathrm{~S}$ production from pancreatic islets and INS-1E cells. ${ }^{6,10}$ In the present study, we further provide evidence that the $\mathrm{H}_{2} \mathrm{~S}$ production rate in the pancreas was significantly decreased in CSE KO mice and that PPG treatment drastically reduced the $\mathrm{H}_{2} \mathrm{~S}$ production rate to near zero in pancreatic islets from wild-type mice. In addition, PPG treatment had a similar effect as CSE KO on repressing STZ-induced hyperglycemia and hypoinsulinemia in mice. We could not detect CBS protein in islets by using homemade anti-CBS antibody and commercially available anti-CBS antibody (Novus Biologicals). In previous studies on rats, we found that treatment of Zuker diabetic fatty rats with PPG brought blood glucose levels to near normal. Conversely, treatment with amino-oxyacetate (AOA), a specific blocker of CBS, did not significantly change the hyperglycemic status of Zuker diabetic fatty rats. ${ }^{10}$ All these data suggest the critical role of CSE-derived $\mathrm{H}_{2} \mathrm{~S}$ in the pathogenesis of diabetes. In contrast, Kaneko et al ${ }^{38}$ recently reported that CBS, but not CSE, was strongly expressed in mouse pancreatic islets by immunohistologic analysis. However, their Western blot analysis results in fact showed more CSE protein expression, taking into account differences in the antibody titers and/or exposure time. ${ }^{38}$ The same authors also reported that the stimulatory effect of L-cysteine on glucose-stimulated insulin release was decreased by PPG treatment, suggestive of the key role of CSE-derived $\mathrm{H}_{2} \mathrm{~S}$ in modulating islet function. ${ }^{8}$ The discrepancy between our results and those of Keneko et al may be related to the differences in the experimental conditions used for the induction of insulin release by glucose or animal species. ${ }^{6,8,10,38}$ Another major difference between these two studies is the opposite effects of $\mathrm{H}_{2} \mathrm{~S}$ on $\beta$-cell apoptosis. One possible reason could be the glucose concentration used. In the study by Kaneko et $\mathrm{al}^{38}$ they found that exposure of cells to high glucose $(20 \mathrm{mmol} / \mathrm{L})$ induced more apoptosis, and supplement of $100 \mu \mathrm{mol} / \mathrm{L} \mathrm{NaHS}$ or $3 \mathrm{mmol} / \mathrm{L}$ cysteine reversed high glucose-induced apoptosis by stimulating intracellular glutathione. The extremely increased $\mathrm{H}_{2} \mathrm{~S}$ production or the direct use of a high concentration of NaHS would cause apoptosis of $\beta$ cells when supplemented with a relatively lower level of glucose $(3 \mathrm{mmol} / \mathrm{L}){ }^{4}$

In conclusion, for the first time we demonstrated that the $\mathrm{CSE} / \mathrm{H}_{2} \mathrm{~S}$ system plays a critical role in regulating $\beta$-cell functions by stimulating $\beta$-cell apoptosis and inducing $\mathrm{K}_{\text {ATP }}$ channel activity and that STZ-induced diabetes is largely mediated by the effect of pancreas-produced $\mathrm{H}_{2} \mathrm{~S}$ on $\beta$-cell mass and $\mathrm{K}_{\text {ATP }}$ channel activity. CSE deficiency significantly delayed the development of STZinduced T1DM. The findings reported herein also indicate that inhibition of the CSE/ $/ \mathrm{H}_{2} \mathrm{~S}$ system is likely to have a beneficial effect when used to prevent or attenuate the progress of diabetes mellitus.

\section{References}

1. Wang R: Hydrogen sulphide: the third gasotransmitter in biology and medicine. Antioxid Redox Signal 2010, 12:1061-1064

2. Wang R: Two's company, three's a crowd: can $\mathrm{H}_{2} \mathrm{~S}$ be the third endogenous gaseous transmitter? FASEB J 2002, 16:1792-1798

3. Zhao W, Zhang J, Lu Y, Wang R: The vasorelaxant effect of $\mathrm{H}_{2} \mathrm{~S}$ as a novel endogenous gaseous $\mathrm{K}_{\text {ATP }}$ channel opener. EMBO $\mathrm{J} 2001$, 20:6008-6016

4. Yang G, Yang W, Wu L, Wang $\mathrm{R}$ : $\mathrm{H}_{2} \mathrm{~S}$, endoplasmic reticulum stress and apoptosis of insulin-secreting beta cells. J Biol Chem 2007, 282:16567-16576

5. Elrod JW, Calvert JW, Morrison J, Doeller JE, Kraus DW, Tao L, Jiao X, Scalia R, Kiss L, Szabo C, Kimura H, Chow CW, Lefer DJ: Hydrogen sulfide attenuates myocardial ischemia-reperfusion injury by preservation of mitochondrial function. Proc Natl Acad Sci U S A 2007, 104:15560-15565

6. Yang W, Yang G, Jia X, Wu L, Wang R: Activation of $\mathrm{K}_{\text {AtP }}$ channels by $\mathrm{H}_{2} \mathrm{~S}$ in rat insulin-secreting cells and the underlying mechanisms. J Physiol 2005, 569(pt 2):519-531

7. Li L, Bhatia M, Moore PK: Hydrogen sulphide: a novel mediator of inflammation? Curr Opin Pharmacol 2006, 6:125-129

8. Kaneko $Y$, Kimura $Y$, Kimura $H$, Niki I: L-cysteine inhibits insulin release from the pancreatic $\beta$-cell: possible involvement of metabolic production of hydrogen sulfide, a novel gasotransmitter. Diabetes 2006, 55:1391-1397

9. Stipanuk MH: Sulfur amino acid metabolism: pathways for production and removal of homocysteine and cysteine. Annu Rev Nutr 2004 24:539-577

10. Wu L, Yang W, Jia X, Yang G, Duridanova D, Cao K, Wang R: Pancreatic islet overproduction of $\mathrm{H}_{2} \mathrm{~S}$ and suppressed insulin release in Zucker diabetic rats. Lab Invest 2009, 89:59-67

11. Yusuf M, Kwong-Huat BT, Hsu A, Whiteman M, Bhatia M, Moore PK: Streptozotocin-induced diabetes in the rat is associated with enhanced tissue hydrogen sulfide biosynthesis. Biochem Biophys Res Commun 2005, 333:1146-1152

12. Herrmann W, Schorr H, Obeid R, Makowski J, Fowler B, Kuhlmann MK: Disturbed homocysteine and methionine cycle intermediates S-adenosylhomocysteine and S-adenosylmethionine are related to degree of renal insufficiency in type 2 diabetes. Clin Chem 2005, 51:891-897

13. Ali MY, Whiteman M, Low CM, Moore PK: Hydrogen sulphide reduces insulin secretion from HIT-T15 cells by a $\mathrm{K}_{\text {ATP }}$ channel-dependent pathway. J Endocrinol 2007, 195:105-112

14. Yang G, Wu L, Jiang B, Yang W, Qi J, Cao K, Meng Q, Mustafa AK, Mu W, Zhang S, Snyder SH, Wang R: $\mathrm{H}_{2} \mathrm{~S}$ as a physiologic vasorelaxant: hypertension in mice with deletion of cystathionine $\gamma$-lyase. Science 2008, 322:587-590

15. O'Brien BA, Harmon BV, Cameron DP, Allan DJ: Beta-cell apoptosis is responsible for the development of IDDM in the multiple low-dose streptozotocin model. J Pathol 1996, 178:176-181 
16. Flodstrom M, Tyrberg B, Eizirik DL, Sandler S: Reduced sensitivity of inducible nitric oxide synthase-deficient mice to multiple low-dose streptozotocin-induced diabetes. Diabetes 1999, 48:706-713

17. Stiles BL, Kuralwalla-Martinez C, Guo W, Gregorian C, Wang Y, Tian $\mathrm{J}$, Magnuson MA, Wu H: Selective deletion of Pten in pancreatic $\beta$ cells leads to increased islet mass and resistance to STZ-induced diabetes. Mol Cell Biol 2006, 26:2772-2781

18. Gier B, Krippeit-Drews P, Sheiko T, Aguilar-Bryan L, Bryan J, Düfer M, Drews $\mathrm{G}$ : Suppression of $\mathrm{K}_{\text {ATP }}$ channel activity protects murine pancreatic $\beta$ cells against oxidative stress. J Clin Invest 2009, 119:32463256

19. Wu L, Noyan Ashraf MH, Facci M, Wang R, Paterson PG, Ferrie A, Juurlink $\mathrm{BH}$ : Dietary approach to attenuate oxidative stress, hypertension, and inflammation in the cardiovascular system. Proc Nat Acad Sci U S A 2004, 101:7094-7099

20. Yang G, Sun X, Wang R: Hydrogen sulfide-induced apoptosis of human aorta smooth muscle cells via the activation of mitogenactivated protein kinases and caspase-3. FASEB J 2004, 18:17821784

21. Mathis $D$, Vence $L$, Benoist $C$ : $\beta$-Cell death during progression to diabetes. Nature 2001, 414:792-798

22. Allison DB, Paultre F, Maggio C, Mezzitis N, Pi-Sunyer FX: The use of areas under curves in diabetes research. Diabetes Care 1995, 18 245-250

23. Meier JJ, Bhushan A, Butler AE, Rizza RA, Butler PC: Sustained $\beta$ cel apoptosis in patients with long-standing type 1 diabetes: indirect evidence for islet regeneration? Diabetologia 2005, 48:2221-2228

24. Johnson JD, Ahmed NT, Luciani DS, Han Z, Tran H, Fujita J, Misler S, Edlund $\mathrm{H}$, Polonsky KS: Increased islet apoptosis in Pdx1+/- mice. $\mathrm{J}$ Clin Invest 2003, 111:1147-1160

25. George M, Ayuso E, Casellas A, Costa C, Devedjian JC, Bosch F: $\beta$ Cell expression of IGF-I leads to recovery from type 1 diabetes. J Clin Invest 2002, 109:1153-1163

26. Hargrove JL, Trotter JF, Ashline HC, Krishnamurti PV: Experimental diabetes increases the formation of sulfane by transsulfuration and inactivation of tyrosine aminotransferase in cytosols from rat liver. Metabolism 1989, 38:666-672
27. Veldman BA, Vervoort G, Blom H, Smits P: Reduced plasma total homocysteine concentrations in Type 1 diabetes mellitus is determined by increased renal clearance. Diabet Med 2005, 22:301-303

28. Wijekoon EP, Hall B, Ratnam S, Brosnan ME, Zeisel SH, Brosnan JT: Homocysteine metabolism in ZDF (type 2) diabetic rats. Diabetes 2005, 54:3245-3251

29. Xue GP, Snoswell AM: Disturbance of methyl group metabolism in alloxan-diabetic sheep. Biochem Int 1985, 10:897-905

30. Lefer DJ: Potential importance of alterations in hydrogen sulphide $\left(\mathrm{H}_{2} \mathrm{~S}\right)$ bioavailability in diabetes. Br J Pharmacol 2008, 155:617-619

31. Brancaleone V, Roviezzo F, Vellecco V, De Gruttola L, Bucci M, Cirino $\mathrm{G}$ : Biosynthesis of $\mathrm{H}_{2} \mathrm{~S}$ is impaired in non-obese diabetic (NOD) mice. Br J Pharmacol 2008, 155:673-680

32. Schnedl WJ, Ferber S, Johnson JH, Newgard CB: STZ transport and cytotoxicity: specific enhancement in GLUT2-expressing cells. Diabetes 1994, 43:1326-1333

33. Turk J, Corbett JA, Ramanadham S, Bohrer A, Mcdaniel ML: Biochemical evidence for nitric oxide formation from streptozotocin in isolated pancreatic islets. Biochem Biophys Res Commun 1993, 197: 1458-1464

34. Xu J, Zhang L, Chou A, Allaby T, Bélanger G, Radziuk J, Jasmin BJ, Miki T, Seino S, Renaud JM: $K_{\text {ATP }}$ channel-deficient pancreatic $\beta$-cells are streptozotocin resistant because of lower GLUT2 activity. Am J Physiol Endocrinol Metab 2008, 294:E326-E335

35. Ashcroft FM: ATP-sensitive $\mathrm{K}^{+}$channels and disease: from molecule to malady. Am J Physiol Endocrinol Metab 2007, 293:E880-E889

36. Miki T, Nagashima H, Tashiro F, Kotake K, Yoshitomi H, Tamamoto A Gonoi T, Iwanaga T, Miyazaki JI, Seino S: Defective insulin secretion and enhanced insulin action in $\mathrm{K}_{\mathrm{ATP}}$ channel-deficient mice. Proc Natl Acad Sci U S A 1998, 95:10402-10406

37. Seino S, Iwanaga T, Nagashima K, Miki T: Perspectives in diabetes: diverse roles of $\mathrm{K}_{\text {ATP }}$ channels learned from Kir62 genetically engineered mice. Diabetes 2002, 49:311-318

38. Kaneko Y, Kimura T, Taniguchi S, Souma M, Kojima Y, Kimura Y, Kimura H, Niki I: Glucose-induced production of hydrogen sulfide may protect the pancreatic $\beta$-cells from apoptotic cell death by high glucose. FEBS Lett 2009, 583:377-382 